\title{
MARKET VALUATION OF THE WORLD'S LEADING PUBLIC OIL AND GAS CORPORATIONS AS AN INDICATOR OF INVESTMENT ATTRACTIVENESS OF DOMESTIC VERTICALLY INTEGRATED COMPANIES"
}

\section{Oleg V. SHIMKO}

Center for Innovative Economics and Industrial Policy,

Institute of Economics of Russian Academy of Sciences (IE RAS),

Balashikha, Moscow Oblast, Russian Federation

shima_ne@mail.ru

https://orcid.org/0000-0002-0779-7097

\section{Article history:}

Article No. 579/2021

Received 25 Oct 2021

Received in revised form

10 November 2021

Accepted 26 Nov 2021

Available online

27 December 2021

JEL: G32, L25, L71, M41, O12

\section{Keywords:}

market capitalization, enterprise value, assets, shareholders' equity, net sales

\begin{abstract}
Subject. This article explores the market valuation ratios of the twenty five leading listed oil and gas companies between 2006 and 2018.

Objectives. The article aims to identify key trends in the changes in market valuations of the largest listed oil and gas companies, and identify the factors that have caused these changes.

Methods. For the study, I used comparative, and financial and economic analyses, and generalization of materials of the companies' consolidated financial statements.

Results. The article shows certain changes in the main indicators of market valuation of the leading listed oil and gas companies and identifies the main factors that contributed to these changes. It establishes that the most significant for comparison and valuation are ratios based on balance sheet values of assets and equity, and net sales, EBITDA, DACF and net income ratios are appropriate as auxiliary ratios. The article says that the exchange segment of the industry has increased the debt load, so instead of market capitalization as a component of the coefficients of this group, it is advisable to apply the enterprise value indicator.

Conclusions and Relevance. The article concludes that the market sentiments towards the stock market segment of the global oil and gas industry are getting impaired. This is quite natural against the background of falling profitability of most leading companies. The results of the study can be useful in evaluating, forecasting and developing measures to increase the market capitalization and value of listed oil and gas companies.
\end{abstract}

(c) Publishing house FINANCE and CREDIT, 2021

The editor-in-charge of this article was Andrey V. Bazhanov

Please cite this article as: Shimko O.V. Market Valuation of the World's Leading Public Oil and Gas Corporations as an Indicator of Investment Attractiveness of Domestic Vertically Integrated Companies. Digest Finance, 2021, vol. 26, iss. 4, pp. 414-433.

https://doi.org/10.24891/df.26.4.414 


\section{Introduction}

For many years, representatives of the Russian economic school have been paying very close attention to various aspects of the financial and economic activities of oil and gas corporations, which are studied using the example of individual companies, as well as at the level of different countries or even on the scale of the entire global industry. Such a pronounced and rather stable interest on the part of the scientific community testifies to the importance of this direction for the country. The oil and gas sector remains the most important component of the entire national economy of the Russian Federation, which has a pronounced raw material nature. This state of the country's economy is reflected in information on the structure of industrial output and export of goods. Therefore, it is quite natural that the aggregate proceeds from the sale of crude oil, natural gas and products of their processing constitute a rather tangible part of the country's budget and, in addition, form the National Welfare Fund of the Russian Federation. Consequently, the largest industry corporations, which are also in key positions in the exchange segment of the country's economy, have a significant impact on the entire national economy.

A characteristic feature of the oil and gas sector of the economy is the instability of prices for extracted raw materials, and therefore the lack of the possibility of their reliable forecasting even for the medium term. In this context, it is noteworthy that before the drop in oil prices, which happened in the conditions of the termination of the agreement to reduce the level of oil production between Russia, Kazakhstan, Azerbaijan and the OPEC member countries and the increase in the pandemic, in the current century there were two other shocks that were quite significant for the global oil and gas industry. First, the global financial crisis and then a prolonged sectoral shock, have already led to a significant reduction in oil prices (Table 1). Meanwhile, in the interval between the above-mentioned crisis phenomena for the industry, oil quotations reached the highest rates. It turns out that since the beginning of the century, average annual oil prices have varied in a very wide range.

It should be noted that oil quotes have a significant impact on the level of profitability and market capitalization indicators of listed companies in the industry. Accordingly, the situation on the world oil market also affects the valuation of oil and gas assets. But the unpredictability of quotations complicates the application of the income approach methods in determining the value of oil and gas assets. Thus, the income capitalization method is based on the relative stability of the net income generated by the company. In turn, the income capitalization method implies the ability to reliably predict further free cash flow of the assessed oil and gas corporation.

In such conditions, when assessing the value of oil and gas assets, the methods of the comparative approach acquire a rather high importance. These methods do not take into

\footnotetext{
"For the source article, please refer to: Шимко О.В. Анализ показателей оценки рынком стоимости ведущих публичных нефтегазовых корпораций мира // Финансы и кредит. 2020. Т. 26, Вып. 12. С. 2765-2789. URL: https://doi.org/10.24891/fc.26.12.2765
} 
account the expectations of investors, but are based on the already available information on concluded deals, on information on exchange trading and data on the results of financial and economic activities of companies. Within the framework of this approach, different indicators of the market's assessment of the company's value are used. Such indicators represent the ratio of certain market parameters to various financial and operating results of activities. The values of such coefficients in determining the value act as multipliers for the corresponding data on the financial and economic activities of the company being assessed.

It turns out that the indicators of the company's valuation by the market reflect the position of investors on the stock exchange regarding the financial and operational results of the listed oil and gas corporation. Therefore, such coefficients are used not only when determining the range of values of non-listed corporations in the industry, but also find application when comparing listed oil and gas companies with their competitors or against the background of the entire industry. The indicators of the market's valuation of the company's value arouse reasonable interest among the domestic scientific community as well. This topic is reflected in the works published by them, which touch upon the relevant aspects of the economic activity of oil and gas corporations.

Thus, the authors turn to market valuation indicators when determining the value of companies [1] within the framework of a comparative approach [2]. It should be noted that such market multipliers are even used to assess the value of the entire Russian stock market, where oil and gas corporations are in the leading roles [3]. Moreover, precisely on the example of listed companies in the oil and gas sector, the specificity of the use of market multipliers [4] is investigated and the features of the valuation [5] and the risks of using such an approach [6] are studied. Consequently, the group's ratios are used to determine the value of the controlling stake [7], to establish the optimal value of the control premium [8], or to identify the synergistic effect [9] in M\&A transactions in the oil and gas sector. The indicators of the analyzed group of financial analysis coefficients are important when analyzing the impact of an unfavorable economic and geopolitical situation on the market value of Russian oil and gas companies [10]. In addition, they are studied when determining the existence of a correlation between the capital structure and the value of industry companies [11].

In addition, the multipliers of the market value of the company are important when analyzing the investment attractiveness [12], operational efficiency, market prospects [13] and the establishment of development factors [14] of listed corporations in the industry. Quite close attention is paid to them when deciding on a buyback of shares [15], as well as studying the reaction of quotations to this procedure [16]. At the same time, the studied coefficients are also used as target indicators for the development of oil companies ${ }^{1}$. Moreover, multipliers are also mentioned in the topics devoted to modeling the sovereign

\footnotetext{
${ }^{1}$ Ulanov V.L. [Docking zones of responsibility for achieving development targets of commodity companies]. Zapiski Gornogo instituta $=$ Notes of the Mining Institute, 2015, no. 211, pp. 117-124. (In Russ.) URL: https://doi.org/10.31897/pmi.2015.1.11775
} 
risk premium in emerging capital markets [17]. It should be noted that the ratios affected by the framework of this study are also considered from the standpoint of making a decision on the placement of free funds [18] in the formation ${ }^{2}$, taking into account the risk, profitability and fair value of the company [19], and subsequent optimization [20] of the investment portfolio.

The number of scientific papers that touch upon various multipliers of the market valuation of oil and gas companies is quite impressive. It is noteworthy that the authors still do not fully cover the direction associated with determining the level of key group coefficients across the entire industry. In addition, the scientific community does not establish the main trends, and also does not determine the most important reasons for the transformations taking place in the entire exchange segment of the oil and gas industry. It is required to take into account the complexity of this kind of research, which consists in the need to collect and process a rather impressive array of information over a long period of time and on a very significant number of listed oil and gas companies. Nevertheless, only if these conditions are met, it is possible to get the most complete picture of the situation with the basic indicators of the market's assessment of the value of oil and gas corporations.

\section{Methodology for compiling a list of the world's leading listed oil and gas corporations}

Meanwhile, when preparing for such a large-scale and laborious study, an important aspect is the choice of those basic approaches, in accordance with which companies are included in the list of leading listed corporations in the global oil and gas sector to form industry indicators. It is quite natural that for listed companies, whose shares are freely quoted on world stock exchanges, market capitalization is the key indicator. Therefore, it is obvious that the market valuation of equity capital should be used as a parameter for ranking companies in order to compile a list of the largest listed corporations in the oil and gas industry, especially in the study of indicators of market valuation of listed oil and gas companies.

In turn, now there are many companies from different industries in the exchange sector of the world economy. In this case, the factor of the availability of reliable sources of information, on the basis of which it is possible to make the correct selection of representatives to complete the list of the largest listed oil and gas corporations in the world for a long period of time, acquires tangible significance. This criterion is met by the Financial Times Global 500 3 list issued until 2015 and the Forbes Global $2000^{4}$ rating still existing, which contains information on the market capitalization of the world's largest

\footnotetext{
${ }^{2}$ Kuznetsova N.V., Kazantsev L.V. [Formation of investment portfolio of a beginning investor]. Vestnik Zabaikal'skogo gosudarstvennogo universiteta $=$ Bulletin of Transbaikal State University, 2018, vol. 24, no. 5, pp. 125-135. (In Russ.) URL: https://doi.org/10.21209/2227-9245-2018-24-5-125-134

${ }^{3}$ FT Global 500 2015. URL: http://im.ft-static.com/content/images/b38c350e-169d-11e5-b07f-00144feabdc0.xls

${ }^{4}$ Forbes Global 2000 2019. URL: http://forbes.com/global2000/list
} 
listed companies. It turns out that it is advisable to include only those companies in the list of leading listed oil and gas corporations required for subsequent analysis that were consistently included in each of the ratings available at that time throughout the entire period of time under study.

Based on the results of a thorough analysis of all sources published in the period covered by the study, it was revealed that only twenty five oil and gas corporations meet the stated conditions. The largest number of companies from the list obtained represent the US oil and gas industry, which is quite expected, because this country has more large listed corporations than any other country in the world. These include well-known multinational integrated corporations such as ExxonMobil and Chevron and the independent companies ConocoPhillips, Occidental Petroleum, Devon Energy, Anadarko Petroleum, EOG Resources, Apache and Marathon Oil.

Moreover, this list also includes oil and gas corporations from another country located in North America - Canada. These are the integrated corporations Imperial Oil, Suncor Energy, Husky Energy and the highly independent Canadian Natural Resources. At the same time, this list also includes one company from South America - the large integrated corporation Petrobras from Brazil. In turn, China is represented by the integrated corporations Sinopec and PetroChina and the independent company CNOOC. Integrated corporations Royal Dutch Shell, BP, TOTAL, Eni and Equinor are concentrated in various countries of Western Europe. In addition the category of integrated corporations includes the largest domestic oil and gas companies, which are PJSC Gazprom, PJSC NK Rosneft and PJSC LUKOIL. All these corporations together form the list of leading listed oil and gas companies, on the basis of which the level of indicators inherent for the industry is formed.

\section{Dynamics of changes in indicators of market valuation of the leading listed oil and gas companies}

It should be noted that one of the most common multipliers in assessing the market attractiveness of listed oil and gas corporations is the ratio of the enterprise value indicator, which consists of the market capitalization and net debt of an oil and gas company, to the existing EBITDA (Table 2). It turns out that the specified multiplier expresses the number of years that a potential investor may need to ensure that the EBITDA generated by the oil and gas corporation, in aggregate, equals the expected costs of acquiring the company itself, without taking into account the current industry level of premium for control over the share capital. Therefore, the considered indicator of market valuation is quite applicable for determining the value of companies within the framework of the comparative approach methods. Moreover, the use of the enterprise value indicator in the structure of the multiplier, rather than market capitalization, is best suited for comparing corporations with significant differences in the level of total debt in the structure of total capital, which is very important in the context of increasing debt burden in the oil and gas industry. 
Based on the results of the analysis, it was found that over the time covered by the study, the inherent level of the enterprise value to EBITDA ratio for the industry decreased (Fig. 1). It is noteworthy that the impact of crises on the value of the indicator was different. Thus, the onset of the global financial crisis in 2008 was accompanied by a noticeable decrease in the ratio of enterprise value to EBITDA, typical for the exchange segment of the oil and gas industry and the subsequent recovery of the value of this indicator was rather short-lived and was again replaced by a decline. On the contrary, the protracted industry shock that began in 2014 led to a tangible increase in the value of the analyzed ratio, but the growth against the background of an increase in average annual oil prices was replaced by an impressive reduction in the ratio of enterprise value to EBITDA.

It is worth noting that during unfavorable for the entire oil and gas industry periods of time the interval of coefficient values among the leading listed oil and gas corporations grows noticeably, which makes it difficult to use this multiplier for comparing and assessing the possible value. Moreover, for some companies EBITDA dropped to negative ranges. During the global financial crisis, a similar situation was noted at Devon Energy. And during the industry turmoil, such results were recorded by Occidental Petroleum, Devon Energy, Anadarko Petroleum and EOG Resources. It turns out that the indicators of the multipliers took negative values for them.

In this case, it can be concluded that the ratio of the enterprise value to EBITDA is most acceptable for comparing and assessing the value of oil and gas corporations during periods of high oil prices, and therefore is more appropriate only as an auxiliary indicator. Meanwhile, in stable conditions for the oil and gas industry and in the absence of specific factors in the formation of EBITDA, the high value of the indicator against the background of competitors expresses the company's great attractiveness for potential investors from the standpoint of assessing future prospects. In turn, with a similar level of debt burden of the compared companies, instead of the enterprise value in the structure of the coefficient, market capitalization is applicable.

Another widely used multiplier is the enterprise value to DACF ratio. The denominator is the corporation's net cash flow from operating activities, summed up with interest expense adjusted by the ratio of income tax expense to earnings before tax (EBT). The ratio under consideration reflects the number of years that a potential investor may need to make the cash received from operating activities equal to the possible costs of acquiring an oil and gas corporation. It is also quite expected that the sectoral level for this multiplier decreased over the period (Fig. 2). Moreover, the ratio of enterprise value to DACF is characterized by features of application and dynamics of change similar to the previous indicator. So, in times of crisis for the entire industry or individual corporations, a low compared to income tax expenses or a negative EBT value can lead to the fact that the value of the enterprise value to DACF ratio will turn out to be quite high against the background of competitors. And in some cases, it will drop below zero, which was observed at Anadarko Petroleum in 2014-2015. 
The next in the list of indicators that are often used in practice for assessing the value of a listed oil and gas corporation by the market is the multiplier, which expresses the ratio of the exchange price of a share to the share of net income per one such security. The ratio demonstrates the number of years it may take to return the initial investment, provided that all the net income of the shareholders of the listed oil and gas company will be used to pay dividends. It turns out that under favorable conditions for the industry, the indicator reflects the market value per unit of corporate income. It should be noted that the ratio level typical for the leading listed companies in the industry has increased (Fig. 3). At the same time, the considered multiplier is more difficult to use in comparison with the previous indicators of the studied group.

Thus, the value of net income is much more susceptible to EBITDA and DACF to changes in oil prices, and therefore, during periods of crisis for the entire industry, it decreases much faster to zero and turns into a negative range of values. Consequently, it is advisable to use this multiplier only during periods favorable for the industry. But even in the context of high oil prices in 2013, the industry indicator was negatively affected by the impressive negative value of Devon Energy's coefficient of $-1,253.54$, without which the multiplier value would have been approximately at 13.19. In addition, another important point is that not all leading listed companies are limited to ordinary shares. There are also corporations that have preferred shares in their share capital. Among the corporations covered by the research framework, these include Petrobras and Husky Energy. In addition, PJSC Surgutneftegas and PJSC ANK Bashneft also hold preferred shares.

The number of such oil and gas companies is rather small, but this aspect can significantly affect the final result. An example of this is Petrobras, which had 37 to $45 \%$ of the total market capitalization on preferred stock within the studied period. In addition, even the common shares of large listed oil and gas companies can be of different types, as is the case with Royal Dutch Shell, PetroChina and Sinopec. Therefore, as an alternative to the indicator, it is better to use the ratio of market capitalization to the company's net profit, which is close in meaning.

Another significant multiplier is the ratio of market capitalization to assets, which is considered the most significant ratio within this group. It should be noted that the value of the typical for the leading listed oil and gas corporations in the industry indicator, expressing the ratio between the market valuation of equity capital and the balance sheet valuation of assets, has significantly decreased over the period studied (Fig. 4), the key reason for which was the global financial crisis. Moreover, after a slight increase in the level during the sectoral crisis, the overall decline continued. It is also important to note that this coefficient is characterized by greater stability of values in comparison with all previous indicators of the group. As well as market capitalization, during long periods of crisis for the industry, the balance sheet value of assets can significantly decline. Nevertheless, the value of the indicator is not capable of reaching zero, which makes its use quite suitable in times of crisis. 
But during industry shocks, the discrepancy between values at the level of individual corporations increases markedly, which is caused by the existing differences in the structure of assets. Integrated corporations have refining and often petrochemical assets, and therefore are not as heavily dependent on oil prices as independent companies. Moreover, during crises, the influence of the asset profitability factor increases. An example of this during a protracted industry crisis is the growth in the highly profitable corporation EOG Resources, which occurred against the backdrop of falling values in the industry, and especially in the company Devon Energy, which has impressive costs per unit of raw materials extracted.

At the same time, the value of the indicator depends on the timeliness of the revaluation of the balance sheet value of assets, especially during periods of shocks. Proved reserves are also becoming increasingly important, which for leading listed companies in the industry is often in the range of 10-15 years. It should be noted that the extremely high provision of reserves, a clear example of which are the data of PJSC Gazprom, does not entail a commensurate increase in the corporation's capitalization. In turn, the low availability of raw materials has a negative impact on the market valuation, as in the case of Husky Energy, Sinopec and Anadarko Petroleum, which was especially evident with the onset of the industry crisis.

Moreover, in terms of multipliers, integrated corporations from the United States significantly outperform the largest domestic companies. This feature confirms the presence of a country factor, the severity of which intensified after the introduction of sectoral sanctions against Russia. In addition, the example of Petrobras, which had a significant increase in the share of borrowed funds in the total structure of total capital after a corruption scandal and revaluation of assets, has a very clear effect on the value of the debt burden ratio. Therefore, to compare and evaluate corporations with a rather different specific component of borrowed capital, instead of market capitalization, it is more expedient to use the enterprise value indicator.

Quite close in nature to the previous group ratio is such a common multiplier as the indicator of the ratio of market capitalization to equity capital. This ratio quite predictably reflects the correlation between the balance sheet and market valuation of the capital of the shareholders of an oil and gas corporation. It is also quite expected that over the period under study, the level of the indicator inherent in the leading listed oil and gas companies has noticeably decreased (Fig. 5), and its dynamics resembled the previous indicator of the group. It turns out that there has been a serious decline in the attractiveness of the exchange segment of the oil and gas industry for investors.

Meanwhile, this multiplier is influenced by all the same factors as the ratio of market capitalization to assets. These include the revaluation of assets, which affects profitability, which, through retained earnings, affects the balance sheet valuation of the share capital. It is also necessary to take into account the debt burden, and therefore, with significant differences in this component, it is better to use the multiplier of the ratio of the enterprise 
value to the share capital for the assessment. At the same time, comparative analysis demonstrates that it is asset-based ratios that are most appropriate for corporate comparisons, rather than equity-based ratios, which then are more suitable as an additional multiplier.

The final indicator among the key coefficients of market valuation of the company's value is the multiplier of the ratio of market capitalization to net sales from operating activities. The use of such a peculiar interpretation of revenue is due to the fact that the industry still lacks a unified approach to the presentation of this indicator in the structure of the income statement. For example, US oil and gas corporations usually do not reflect royalties in their revenues, but companies from Canada started such a practice only 10 years ago. In addition, not all oil and gas corporations in Canada indicate excise taxes, duties, and all other taxes that are not related to income tax in their cost structure. At the same time, the largest domestic companies include excise taxes and export duties in their own revenues. Moreover, the reporting structure of the world's leading listed oil and gas corporations is capable of transforming over time, as exemplified by ExxonMobil, which since $2017^{5}$ has ceased to take into account sales taxes as part of its costs, and therefore has also cleared its revenue from this component.

Therefore, for a correct comparison, one should use such a component that is freely determined for all, without exception, large listed companies in the industry. This indicator is the net revenue from the main activity, which for the industry company is the sale of its own and marketing resale of purchased reserves of oil, gas condensate, natural gas and refined and petrochemical products. This component of revenue does not include all proceeds from non-operating activities, as well as payments of royalties, excise taxes, export duties and other taxes that are not related to income tax. It is this metric that is best suited for comparing and assessing the potential value of oil and gas corporations on a revenue basis.

It should be noted that the level of the typical for leading listed oil and gas corporations ratio of market capitalization to net sales from operating activities has also significantly decreased (Fig. 6). It is noteworthy that before the global financial crisis, as well as in the midst of both shocks, the multiplier reached its highest values. It turns out that the market valuation of companies in the industry, although it depends on oil prices, is not so pronounced. It is quite natural that the significant, against the background of competitors in the industry, the value of the coefficient should indicate a higher assessment of the company's performance by investors, but in this case there are certain nuances. Thus, the value of the indicator is influenced by the same factors that are inherent in the other studied multipliers of the group of coefficients for assessing the company's value by the market.

\footnotetext{
${ }^{5}$ Form 10-K Annual Report Pursuant to Section 13 or 15 (d) of the Securities Exchange Act of 1934 for the Fiscal Year Ended December 31, 2017. Exxon Mobil Corporation.

URL: https://sec.gov/Archives/edgar/data/34088/000003408818000015/xom10k2017.htm
} 
But there is also a peculiarity inherent in the indicator under study, which is that the cost of refined and petrochemical products per barrel of oil equivalent is usually much higher than that of crude oil and natural gas, and therefore, with an increase in the degree of vertical integration of the corporation, the value of the coefficient begins to decrease. A good example of this is the indicators of integrated and independent corporations in the United States. In addition, the market valuation is weakly reflected in the increase in revenue due to the resale and processing of purchased raw materials. This is noticeable in the multiples of such companies as Devon Energy, Sinopec and PJSC LUKOIL, whose share of corresponding receipts in the total sales structure is rather high against the background of other leading public oil and gas corporations in the world.

\section{Conclusions}

The research carried out on all key indicators of the company's valuation by the market made it possible to assess how the attitude of investors towards the exchange sector of the oil and gas industry has changed over the period studied, as well as to establish what had the most serious impact on the coefficients. It was revealed that the decrease in the level of values of most of the studied typical for the leading listed oil and gas corporations indicators was to the greatest extent due to the global financial crisis. It was also established that, despite some recovery during the protracted sectoral crisis, the decline continued. Consequently, the market worsened its own attitude towards the exchange segment of the global oil and gas industry, which is quite natural against the background of falling profitability of most leading companies. But it is especially worth highlighting the domestic oil and gas corporations, whose indicators, in addition to everything, were influenced by the sectoral sanctions imposed against the Russian Federation.

In addition, it was determined that the most significant from the point of view of comparison and valuation within this group of indicators are the ratios expressing the ratio of market capitalization or enterprise value to assets or share capital. Multipliers based on net sales from operating activities are also applicable. It was also revealed that indicators based on EBITDA, DACF and net income of shareholders are more acceptable as auxiliary ratios only in favorable periods of high oil prices. At the same time, the industry's debt burden has grown, and therefore, instead of market capitalization, it is advisable to use the enterprise value indicator. Meanwhile, it is necessary to take into account the effect on the level of the values of the multipliers other important factors, among which it is required to highlight the indicators of profitability, the structure of assets and net sales. 
Table 1

The average price for WTI and Brent crude oil for 1999-2018, USD per barrel

\begin{tabular}{|c|c|c|c|c|c|c|c|c|c|c|}
\hline Oil grade & 1999 & 2000 & 2001 & 2002 & 2003 & 2004 & 2005 & 2006 & 2007 & 2008 \\
\hline WTI & 19.34 & 30.38 & 25.98 & 26.18 & 31.08 & 41.51 & 56.64 & 66.05 & 72.34 & 99.67 \\
\hline Brent & 17.9 & 28.66 & 24.46 & 24.99 & 28.85 & 38.26 & 54.57 & 65.16 & 72.44 & 96.94 \\
\hline \multicolumn{11}{|c|}{ Continuation of the table } \\
\hline Oil grade & 2009 & 2010 & 2011 & 2012 & 2013 & 2014 & 2015 & 2016 & 2017 & 2018 \\
\hline WTI & 61.95 & 79.48 & 94.88 & 94.05 & 97.98 & 93.17 & 48.66 & 43.29 & 50.8 & 65.23 \\
\hline Brent & 61.74 & 79.61 & 111.26 & 111.63 & 108.56 & 98.97 & 52.32 & 43.64 & 54.13 & 71.34 \\
\hline
\end{tabular}

Source: Authoring, based on the U.S. Energy Information Administration data. URL: https://eia.gov

Table 2

The average values of the key market valuations of the twenty five leading listed oil and gas corporations for 2006-2018, million USD

\begin{tabular}{|c|c|c|c|c|c|c|c|}
\hline Index & $\begin{array}{l}31.12 . \\
2006\end{array}$ & $\begin{array}{l}31.12 \\
2007\end{array}$ & $\begin{array}{l}31.12 . \\
2008\end{array}$ & $\begin{array}{l}31.12 . \\
2009\end{array}$ & $\begin{array}{l}31.12 \\
2010\end{array}$ & $\begin{array}{l}31.12 . \\
2011\end{array}$ & $\begin{array}{l}31.12 . \\
2012\end{array}$ \\
\hline Enterprise value to EBITDA & 5.87 & 7.3 & 5.87 & 6.29 & 6.58 & 5.71 & 4.82 \\
\hline Enterprise value to DACF & 8.48 & 9.74 & 4.84 & 9.67 & 7.47 & 5.94 & 5.74 \\
\hline Common stock price-to-earnings ratio & 10.97 & 13.97 & 7.22 & 2.14 & 16.93 & 7.91 & 8.01 \\
\hline Market capitalization-to-assets ratio & 1.38 & 1.62 & 0.84 & 1.01 & 0.91 & 0.76 & 0.7 \\
\hline $\begin{array}{l}\text { Market capitalization-to-shareholders' } \\
\text { equity ratio }\end{array}$ & 2.78 & 3.17 & 1.64 & 1.97 & 1.76 & 1.5 & 1.37 \\
\hline Market capitalization-to-net sales ratio & 2.09 & 2.67 & 1.14 & 2.35 & 1.89 & 1.39 & 1.37 \\
\hline \multicolumn{8}{|l|}{ Continuation of the table } \\
\hline Index & $\begin{array}{l}31.12 . \\
2013\end{array}$ & \multicolumn{2}{|c|}{$\begin{array}{l}31.12 . \\
2014\end{array}$} & $\begin{array}{l}31.12 . \\
2015\end{array}$ & $\begin{array}{l}31.12 . \\
2016\end{array}$ & $\begin{array}{l}31.12 . \\
2017\end{array}$ & $\begin{array}{l}31.12 . \\
2018\end{array}$ \\
\hline Enterprise value to EBITDA & 5.15 & \multicolumn{2}{|c|}{6.1} & 8.05 & 10.94 & 7.21 & 4.75 \\
\hline Enterprise value to DACF & 6.2 & \multicolumn{2}{|c|}{5.14} & 5.97 & 12.51 & 8.49 & 5.54 \\
\hline Common stock price-to-earnings ratio & -37.52 & \multicolumn{2}{|c|}{16.35} & 4.99 & 53.85 & -14.38 & 21.75 \\
\hline Market capitalization-to-assets ratio & 0.69 & \multicolumn{2}{|c|}{0.62} & 0.56 & 0.72 & 0.71 & 0.61 \\
\hline $\begin{array}{l}\text { Market capitalization-to-shareholders' } \\
\text { equity ratio }\end{array}$ & 1.39 & \multicolumn{2}{|c|}{1.28} & 1.42 & 1.72 & 1.57 & 1.32 \\
\hline Market capitalization-to-net sales ratio & 1.41 & \multicolumn{2}{|c|}{1.26} & 1.51 & 2.38 & 1.82 & 1.23 \\
\hline
\end{tabular}

Source: Authoring, based on [21] 


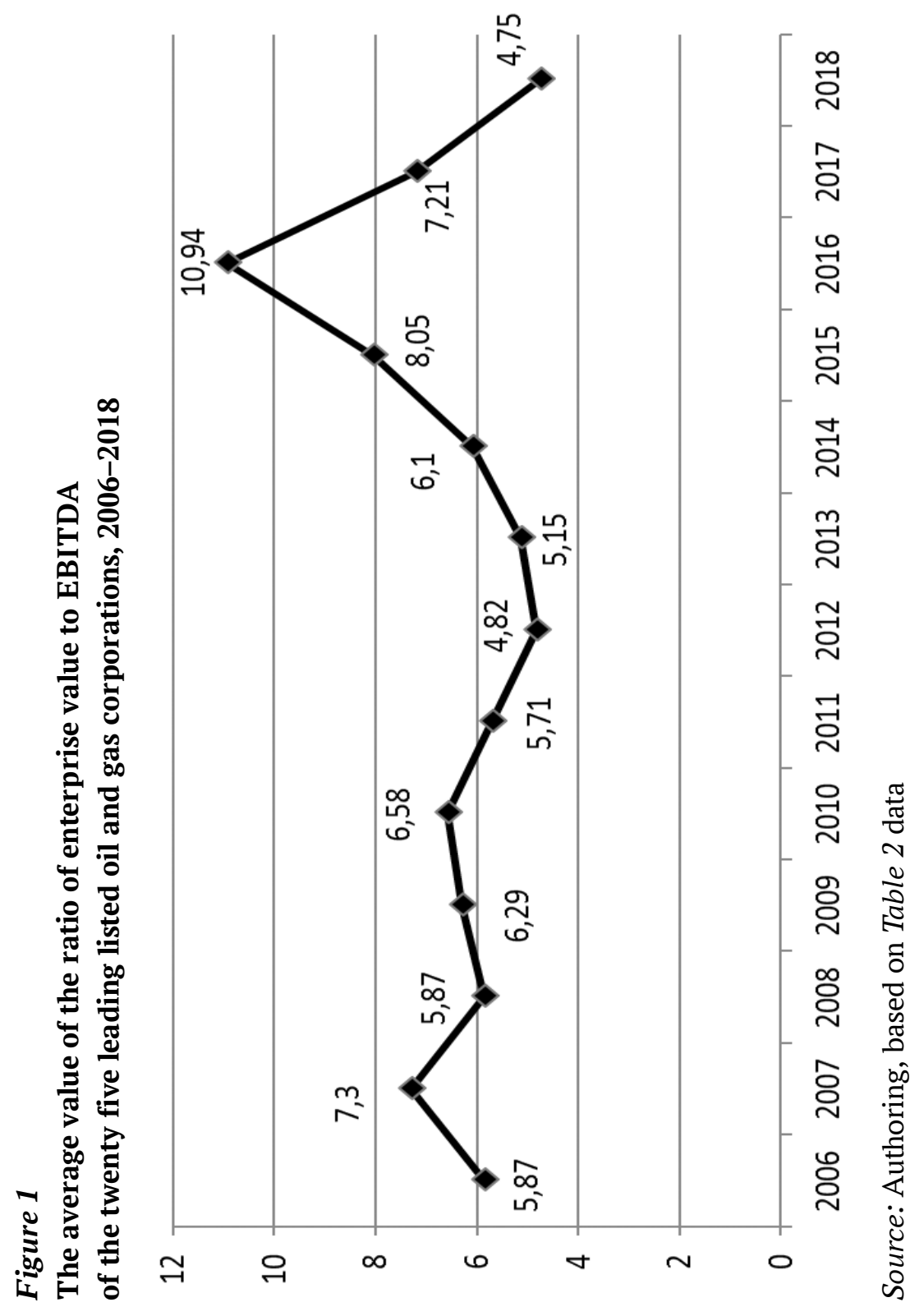




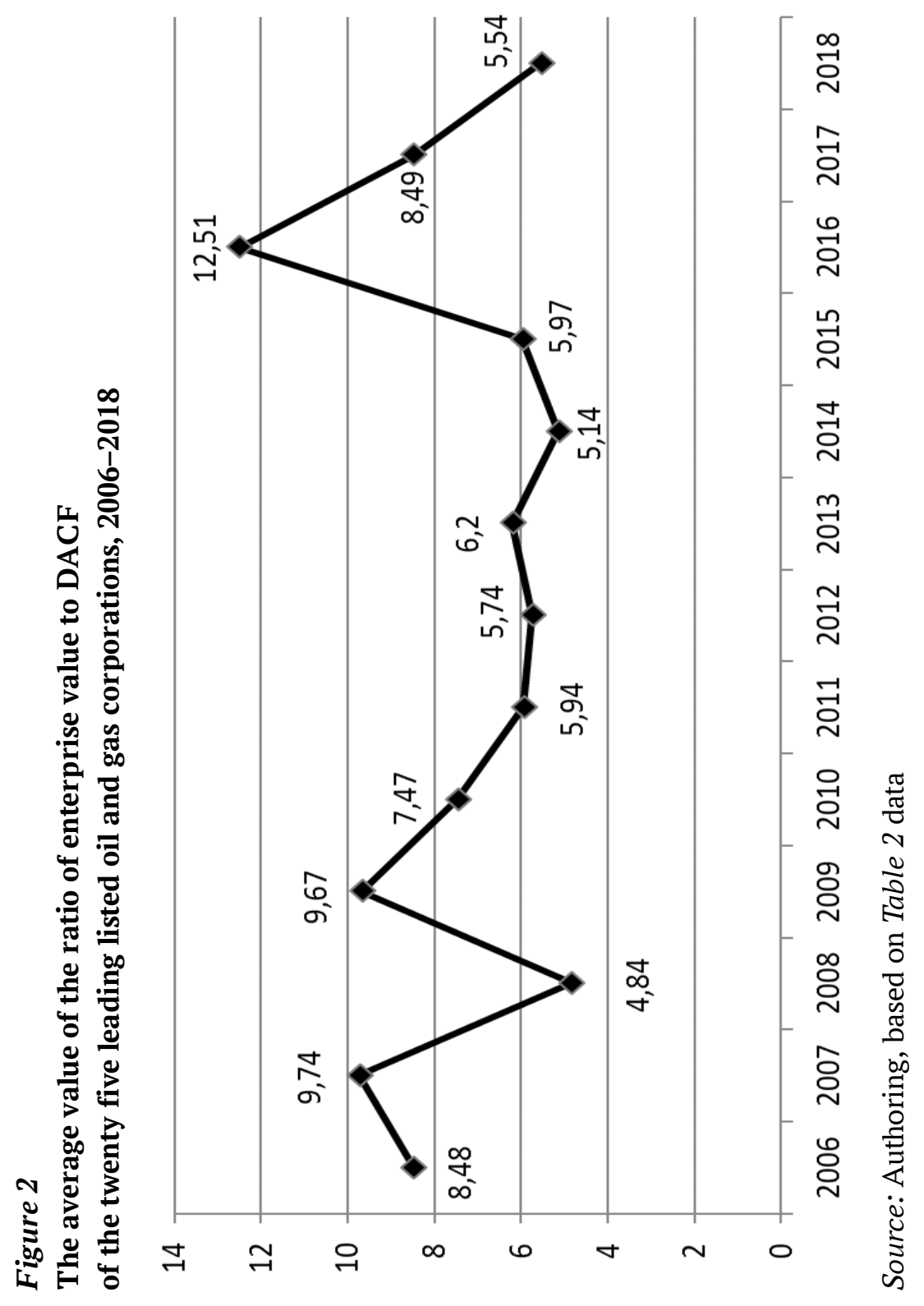




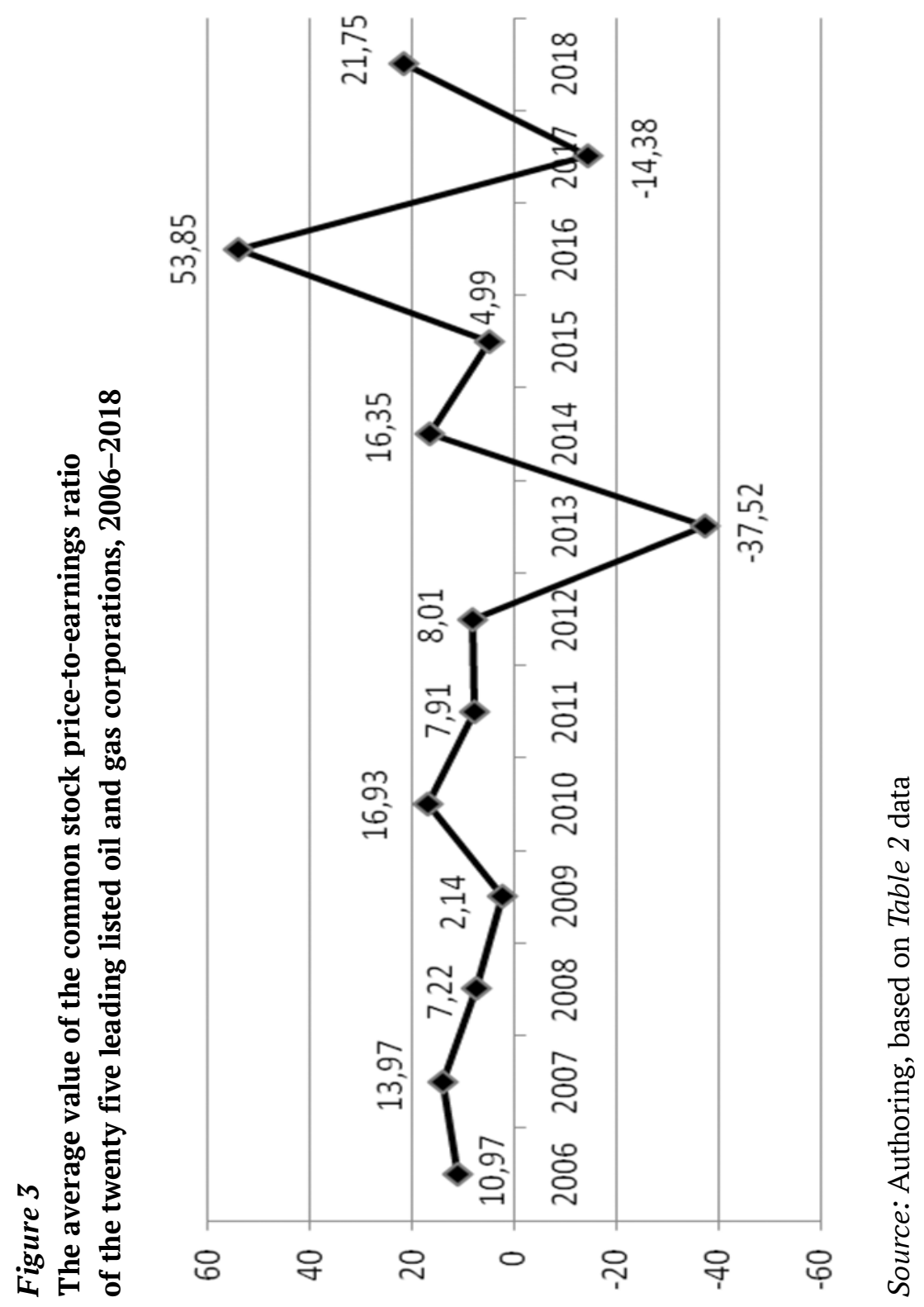




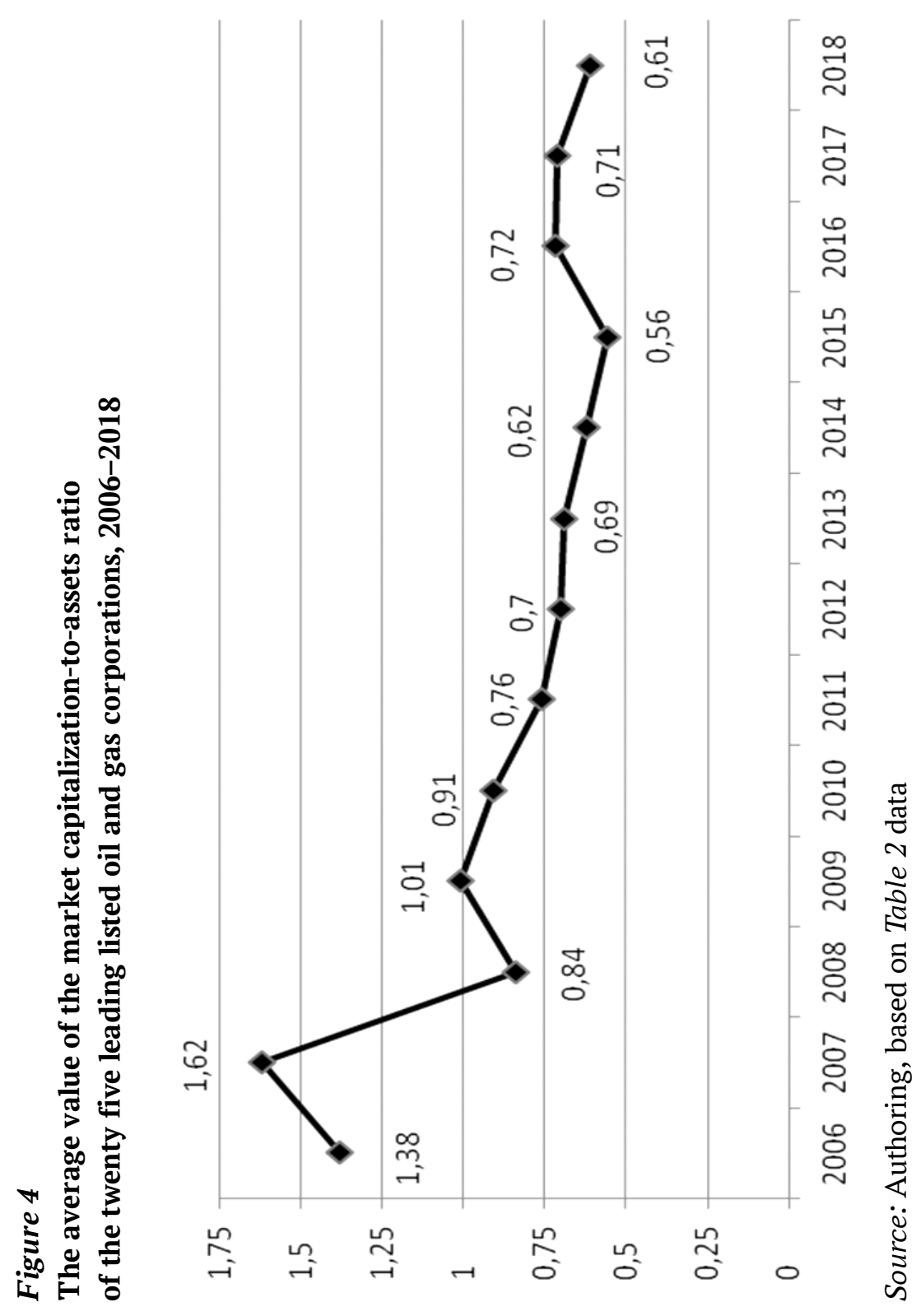




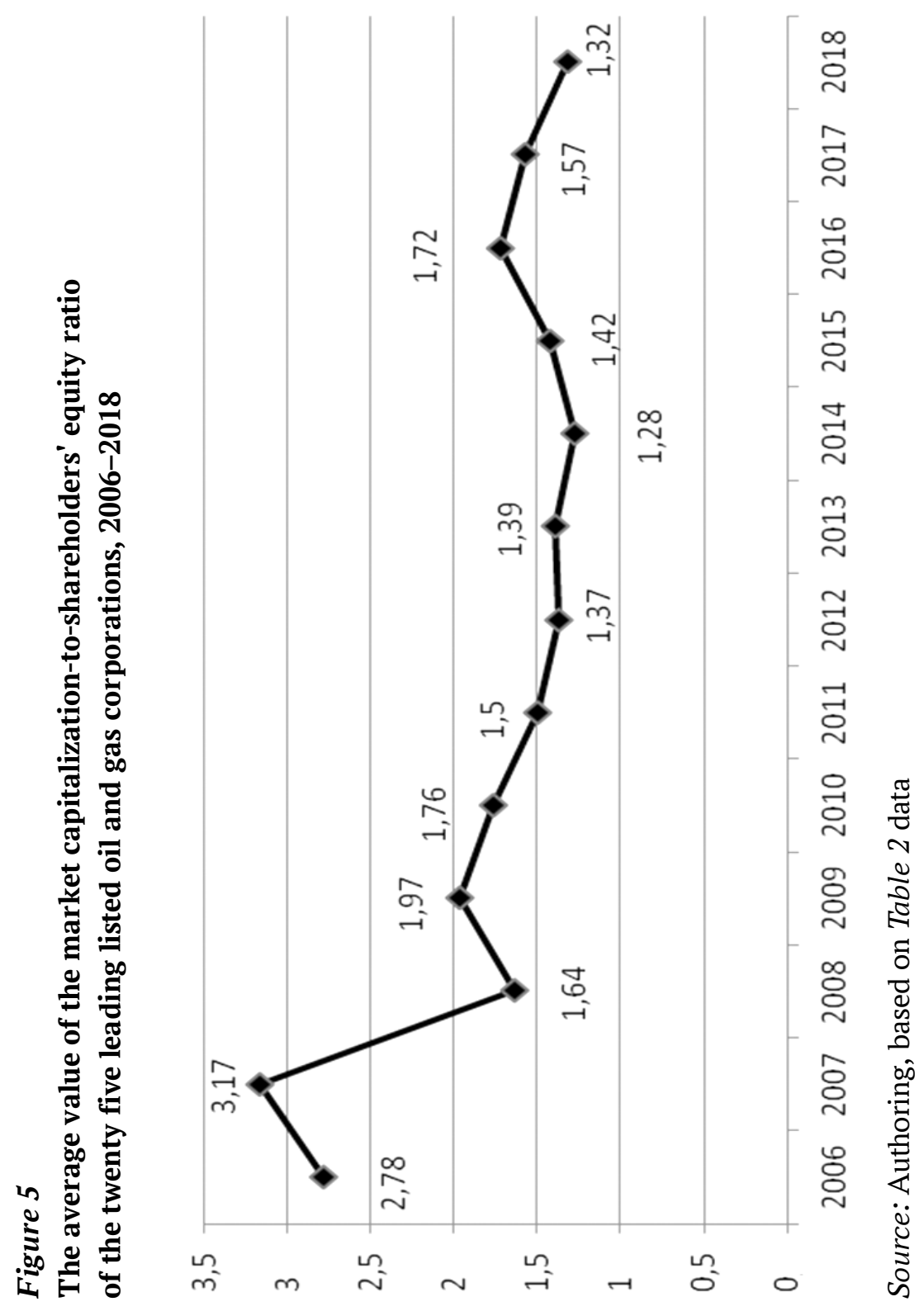




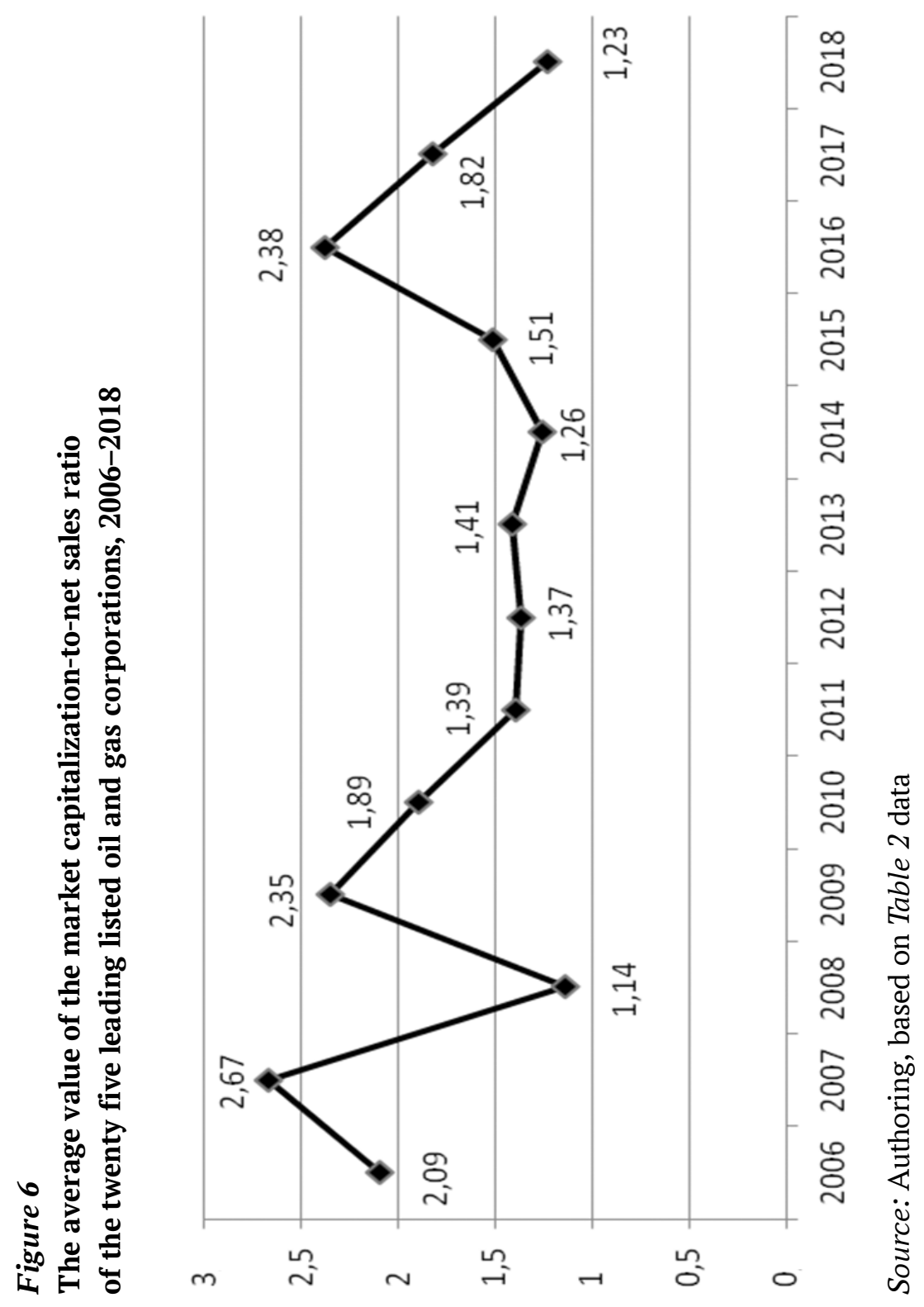




\section{References}

1. Kozlova A.S., Odinokova K.A., Taraskin D.S. [Most popular approaches to valuation of public companies]. Vestnik Saratovskogo gosudarstvennogo sotsial'noekonomicheskogo universiteta $=$ Bulletin of Saratov State Socio-Economic University, 2019, no. 1, pp. 105-111. URL: https://cyberleninka.ru/article/n/osnovnye-podhody-kotsenke-stoimosti-publichnyh-kompaniy (In Russ.)

2. Kokin A.S., Oskolkov I.M., Syzganova A.A. [Comparative approach to estimation of cost of stocks of the oil and gas companies of Russia on the basis of the fundamental analysis]. Ekonomika: vchera, segodnya, zavtra = Economics: Yesterday,Today and Tomorrow, 2019, vol. 9, no. 1-1, pp. 241-258.

URL: http://publishing-vak.ru/file/archive-economy-2019-1/25-kokin.pdf (In Russ.)

3. Khasanov R.Kh., Lavrinenko A.O. [Valuation of the Russian stock market]. Finansovaya analitika: problemy i resheniya = Financial Analytics: Science and Experience, 2017, vol. 10, iss. 3, pp. 311-330. (In Russ.)

URL: https://doi.org/10.24891/fa.10.3.311

4. Minasyan V.B. [Assessment of risks arising from the use of multiplier technology to assess the shares]. Finansy: teoriya i praktika = Finance: Theory and Practice, 2018, vol. 22, no. 3, pp. 124-135. (In Russ.)

URL: https://doi.org/10.26794/2587-5671-2018-22-3-124-135

5. Ivko D.G. [Peculiarities of assessing Russian companies' value by using the method of market multipliers]. Finansy $i$ upravlenie $=$ Finance and Management, 2017, no. 1, pp. 34-46. (In Russ.) URL: https://doi.org/10.7256/2409-7802.2017.1.22087

6. Minasyan V.B., Ivko D.G. [Model risk analysis of multiplier technology applied at stock valuation of Russian companies]. Finansy: teoriya i praktika = Finance: theory and practice, 2019, no. 23, no. 6, pp. 91-116. (In Russ.)

URL: https://doi.org/10.26794/2587-5671-2019-23-6-91-116

7. Khalikova M.A., Belai I.E., Galimzyanov R.N. [The evaluation of a controlling stake of the oil company]. Internet-zhurnal Naukovedenie, 2016, vol. 8, no. 3. (In Russ.) URL: http://naukovedenie.ru/PDF/114EVN316.pdf

8. Nazarova V.V., Shevyakina O.R. [Determination of an optimum premium paid in M\&A transactions in oil and gas section]. Korporativnye finansy = Journal of Corporate Finance Research, 2015, vol. 9, no. 4, pp. 5-30. (In Russ.) URL: https://doi.org/10.17323/j.jcfr.2073-0438.9.4.2015

9. Garifullin F.F. [Synergistic effect as basis for its decision to hold the mergers and acquisitions]. Vestnik Universiteta (Gosudarstvennyi universitet upravleniya), 2015, no. 2, pp. 156-159. URL: https://cyberleninka.ru/article/n/sinergeticheskie-effekty- 
kak-osnova-dlya-prinyatiya-resheniy-o-provedenii-sdelok-sliyaniy-i-pogloscheniy (In Russ.)

10.Lipatnikov V.S., Kirsanova K.A. [Assessment of the impact of the adverse economic geopolitical environment on the worth of Russian oil and gas companies].

Upravlencheskie nauki = Management Sciences, 2018, vol. 8, no. 2, pp. 30-43. (In Russ.) URL: https://doi.org/10.26794/2404-022X-2018-8-2-30-43

11. Chernenko V.A., Burov A.N. [Russian and global capital structure approach: enterprise value impact]. Izvestiâ Sankt-Peterburgskogo gosudarstvennogo èkonomičeskogo universiteta, 2019, no. 1, pp. 38-42.

URL: https://unecon.ru/sites/default/files/izvestiya_no_1-2019.pdf (In Russ.)

12. Basiladze G.R. [Comparative analysis of investment appeal of PJSC “Lukoil”, PJSC "Rosneft”, PJSC “Gazprom”]. Gumanitarnye, sotsial'no-ekonomicheskie $i$ obshchestvennye nauki = Humanities, Social-Economic and Social Sciences, 2017, no. 1, pp. 145-147. URL: https://cyberleninka.ru/article/n/sravnitelnyy-analizinvestitsionnoy-privlekatelnosti-pao-lukoyl-pao-rosneft-pao-gazprom (In Russ.)

13. Tebekin A.V. [Analysis of the prospects for the implementation of the energy strategy of the Russian Federation in terms of the transportation of energy resources]. Strategii biznesa $=$ Strategies of Business, 2019, no. 3, pp. 11-21. (In Russ.)

URL: https://doi.org/10.17747/2311-7184-2019-3-11-21

14. Vasil'eva E.V., Petrova S.B. [Strategic analysis of factors affecting the development of oil and gas corporations in Russia]. Vestnik Ekaterininskogo instituta $=$ Bulletin of Catherine the Great National Institute, 2015, no. 2, pp. 8-14. (In Russ.)

15.Ponomareva S.V., Zheleznova I.V. [Features of share buybacks in Russia]. Vestnik Permskogo natsional'nogo issledovatel'skogo politekhnicheskogo universiteta. Sotsial'no-ekonomicheskie nauki = PNRPU Sociology and Economics Bulletin, 2017, no. 2, pp. 165-178. (In Russ.) URL: https://doi.org/10.15593/2224-9354/2017.2.13

16.Zheleznova I.V. [The stock price dynamic model during share buybacks]. Vestnik Permskogo natsional'nogo issledovatel'skogo politekhnicheskogo universiteta. Sotsial'no-ekonomicheskie nauki = PNRPU Sociology and Economics Bulletin, 2017, no. 3, pp. 223-240. (In Russ.) URL: https://doi.org/10.15593/2224-9354/2017.3.19

17. Timofeev D.V. [Modeling of a sovereign risk premium in emerging capital markets]. Korporativnye Finansy = Journal of Corporate Finance Research, 2015, vol. 9, no. 2, pp. 54-75. (In Russ.) URL: https://doi.org/10.17323/j.jcfr.2073-0438.9.2.2015.54-75

18. Bessonova A.A., Belousova N.D. [Accommodation of free cash flows of physical persons: deposits and securities]. Azimut nauchnykh issledovanii: ekonomika $i$ upravlenie = Azimuth of Scientific Research: Economics and Administration, 2018, 
vol. 7 , no. 2 , pp. $48-51$.

URL: http://rupaaspk.beget.tech/wp-content/plugins/download-attachments/includes/ download.php?id=2375 (In Russ.)

19. Kozlova A.S., Taraskin D.S. [Methodology for forming securities portfolio based on risk, yield and fair value of the company]. Vestnik Saratovskogo gosudarstvennogo sotsial'no-ekonomicheskogo universiteta $=$ Bulletin of Saratov State Socio-Economic University, 2018, no. 1, pp. 104-109. URL: https://cyberleninka.ru/article/n/metodikaformirovaniya-portfelya-tsennyh-bumagna-osnove-riska-dohodnosti-i-spravedlivoystoimosti-kompanii (In Russ.)

20. Gurvits Yu.B. [The development of strategy for stock portfolio optimization in oil and gas sector]. Vestnik Moskovskogo universiteta. Seriya 6: Ekonomika = Moscow University Economics Bulletin, 2017, no. 2, pp. 65-89.

URL: https://www.econ.msu.ru/sys/raw.php?o=39325\&p=attachment (In Russ.)

21. Shimko O.V. Analiz rezul'tatov finansovo-khozyaistvennoi deyatel'nosti vedushchikh publichnykh korporatsii neftegazovoi otrasli posle mirovogo finansovogo krizisa [An analysis of the results of financial and economic activities of leading public corporations in the oil and gas industry after the global financial crisis]. Moscow, Nauka Publ., 2019, 339 p.

\section{Conflict-of-interest notification}

I, the author of this article, bindingly and explicitly declare of the partial and total lack of actual or potential conflict of interest with any other third party whatsoever, which may arise as a result of the publication of this article. This statement relates to the study, data collection and interpretation, writing and preparation of the article, and the decision to submit the manuscript for publication. 